\title{
Securing the sea: ecosystem-based adaptation and the biopolitics of insuring nature's rents
}

\author{
Jens Christiansen $^{1}$ \\ Lancaster University, UK
}

\begin{abstract}
With the emergence of the so-called Blue Economy, various conservation finance mechanisms and financial structures are being proposed as a means of simultaneously securing marine biodiversity and profit-making. A novel approach that is being applied within this new conservation finance frontier is the integration of ecosystem-based adaptation and insurance. By synthesizing recent literatures in political ecology on the notion of rent and the biopolitics of nature, this article explores how the integration of ecosystem-based adaptation and insurance can be seen as a technique that is mobilized for governing ecosystem rents biopolitically. The article urges political ecologists to pay attention to how biopolitics and governance of rents intersect in market-based environmental governance. While surveying the breadth of projects that involves both adaptation and insurance, I pay particular attention to a parametric coral reef insurance that was recently introduced in the Mexican state Quintana Roo. Such a project, this article argues, involves reconceptualizing the coral reef as an infrastructure that provides benefits - ultimately rents - to the local tourist industry and indirectly the state, but this coral infrastructure is itself in need of being protected through insurance as a biopolitical measure that can ensure the future life of the coral reef by rendering calculable uncertain, future climate threats to the reef. By reconceptualizing ecosystems as infrastructure that can be insured, the notion of ecosystem-based adaptation operationalizes otherwise systematic risks posed by climate change and biodiversity loss on a local scale. Finally, I highlight some of the complications that are involved when insurance is used as a biopolitical means of making nature live.
\end{abstract}

Key words: nature-based solutions (NbS), financialization, neoliberal natures, insurance, Blue Economy, conservation, biopolitics, blue-green infrastructure

\section{Résumé}

Avec l'émergence de ce qu'on appelle l'Économie Bleue, divers mécanismes et structures de financement pour la conservation de la nature sont proposés comme moyen de garantir simultanément la biodiversité marine et la rentabilité. Une nouvelle approche appliquée à cette nouvelle frontière du financement de la conservation est l'intégration de l'adaptation basée sur les écosystèmes et l'assurance. En synthétisant la littérature récente en écologie politique sur la notion de rente et la biopolitique de la nature, cet article examine comment l'intégration de l'adaptation basée sur les écosystèmes et l'assurance peut être considérée comme une technique mobilisée pour gouverner les rentes des écosystèmes de manière biopolitique. L'article exhorte les écologistes politiques à prêter attention à la manière dont la biopolitique et la gouvernance des rentes s'entrecroisent dans la gouvernance environnementale basée sur le marché. Tout en examinant l'étendue des projets qui impliquent à la fois l'adaptation et l'assurance, j'accorde une attention particulière à une assurance paramétrique des récifs coralliens récemment introduite dans l'État mexicain de Quintana Roo. Cet article soutient qu'un tel projet nécessite de reconceptualiser le récif corallien comme une infrastructure qui fournit des avantages - en fin de compte des rentes - à l'industrie touristique locale et indirectement à l'État. Mais, cette infrastructure corallienne

\footnotetext{
${ }^{1}$ Jens Christiansen, PhD Candidate, Lancaster Environment Centre, Lancaster University, UK. Email: j.christiansen "at" lancaster.ac.uk. The author would like to thank Patrick Bigger, Sara Nelson, Fernanda Rojas Marchini, Jessica Dempsey, Liz Shapiro, Andrea Gonzalez Natera, Zac Taylor, Lisa Boström-Einarsson, Audrey Irvine-Broque, Christina Hicks and two anonymous reviewers for comments on an earlier draft. I extend huge thanks to Guy Crawford and Anna Woodhead for translating the abstract. I would especially like to thank all interviewees for sharing their time and insights. Funding is acknowledged from the Social Sciences and Humanities Research Council of Canada as well as a PhD scholarship from Lancaster Environment Centre, Lancaster University, UK.
} 
a elle-même besoin d'être protégée par l'assurance comme une mesure biopolitique qui peut garantir la vie future du récif corallien en rendant calculables les menaces climatiques futures et incertaines. En reconceptualisant les écosystèmes comme des infrastructures qui peuvent être assurées, la notion d'adaptation basée sur les écosystèmes opérationnalise les risques autrement systématiques posés par le changement climatique et la perte de biodiversité à l'échelle locale. Enfin, je souligne des complications impliquées lorsque l'assurance est utilisée comme un moyen biopolitique de faire vivre la nature.

Mots clés: solutions basées sur la nature (NbS), financiarisation, natures néolibérales, assurance, Économie Bleue, conservation de la nature, biopolitique, trame verte et bleue

\section{Resumen}

Con el surgimiento de la llamada Economía Azul, se proponen varios mecanismos y estructuras financieras de conservación como un medio para asegurar simultáneamente la biodiversidad marina y la rentabilidad. Un enfoque novedoso que se aplica dentro de esta nueva frontera de las finanzas de la conservación es la integración de la adaptación basada en los ecosistemas y los seguros. Al sintetizar la literatura reciente en ecología política sobre la noción de renta y la biopolítica de la naturaleza, este artículo explora cómo la integración de la adaptación basada en los ecosistemas y los seguros puede verse como una técnica que se moviliza para gobernar las rentas de los ecosistemas de forma biopolítica. El artículo insta a los ecologistas políticos a prestar atención a cómo la biopolítica y la gobernanza de las rentas convergen en la gobernanza ambiental basada en el mercado. Mientras analizo la amplitud de los proyectos que involucran la adaptación y los seguros, presto atención especial a un seguro paramétrico de arrecife coralino que se introdujo recientemente en el estado mexicano de Quintana Roo. Tal proyecto, argumenta este artículo, implica reconceptualizar el arrecife de coral como una infraestructura que proporciona beneficios, rentas, a la industria turística local e indirectamente al estado, pero esta infraestructura coralina necesita ser protegida a través de seguros como una medida biopolítica que puede garantizar la vida futura del arrecife de coral al hacer que las inciertas amenazas climáticas futuras para el arrecife sean calculables. Al reconceptualizar los ecosistemas como infraestructura que puede ser asegurada, la noción de adaptación basada en los ecosistemas operacionaliza los riesgos que de otro modo serían sistemáticos planteados por el cambio climático y la pérdida de biodiversidad a escala local. Finalmente, destaco algunas de las complicaciones que se presentan cuando los seguros se utilizan como un medio biopolítico para hacer que la naturaleza viva.

Palabras clave: Soluciones basadas en la naturaleza, financialización, neoliberalización del medio ambiente, seguros, Economía Azúl, conservación, biopolítica, infraestructura azul-verde

\section{Introduction}

"The first ever insurance policy on nature", this is how The Nature Conservancy (TNC) frames their parametric coral reef insurance, which they developed in the Mexican state Quintana Roo in collaboration with insurance company Swiss Re and the Rockefeller Foundation (Artemis, 2017). Whilst defining nature - and thus what qualifies as an "insurance policy on nature" - is a complex task (Braun, 2009 p. 20), one novel aspect is evident: this was the first time that an ecosystem, a commons, has been insured parametrically. Such parametric techniques base insurance payouts on a statistical trigger rather than actual damages to assets. Following the insurance industry's historical ability to expand what is insurable (Johnson, 2011; Scherer, 2020), a remarkable feature of the Quintana Roo parametric reef insurance is that no one "owns" the reef (Kousky and Light, 2019). This coral reef insurance is but one recent example of how climate change adaptation and biodiversity conservation is simultaneously addressed through insurance and ecosystem-based adaptation.

The insurance policy was built on the overarching argument that the reef serves as a critical protective infrastructure for the tourist industry in the area. Thus, according to TNC, there is an incentive to protect the reef from hurricanes. Together with their partners, TNC has built a statistical model for how strong a hurricane would have to be, to be correlated with reef damage. If a hurricane above 100 knots hits the specified area where the reefs are located, it would result in a payout to the newly established Coastal Zone Management Trust. The payout can then be used to finance a clean-up by an immediate response team or be used to finance reconstruction of the reef (Berg et al., 2020, p. 16; Secaira Fajardo et al., 2019). While TNC's coral reef insurance is one that has received a lot of publicity, several other projects currently try to integrate ecosystem- 
based adaptation and insurance (Beck et al., 2019; Conway and Mazza, 019; Willis Towers Watson and MAR Fund, 2019a).

The aim of this article is to critically reflect on the integration of ecosystem-based adaptation and insurance, through the concepts of rent and biopolitics as they have recently been applied in political ecology literature. The article thus makes two contributions: the theoretical contribution is to synthesize political ecology literature on rents and biopolitics to show how the rents that specific actors receive as free gifts of nature are governed biopolitically. As insurance researchers acknowledge (Bougen, 2003; Johnson, 2013a), risk needs to be actively constructed (Douglas \& Wildavsky, 1983). However, some threats can even be acknowledged as risks at an emic level without being subjected to formal calculation (Boholm, 2003). This study shows how the boundary between risk and uncertainty is constructed when an ecosystem becomes rentbearing as infrastructure (Nelson and Bigger, 2021), and the risk of damage to the ecosystem by hurricanes is subjected to insurance calculations.

Secondly, by fleshing out the logic underpinning the integration of ecosystem-based adaptation and insurance - by asking what kind of value, if any, do protective ecosystems represent to capital - this paper offers an analysis of how "nature-based solutions" are rendered financial. In short, the promise of insurance as biopolitical governance of rent is that risks to ecosystems' rents can be rationally calculated and potentially mitigated, if only partially, by capital. Insurance products for nature remain an emerging phenomenon, despite having been underway for some time (Nelson, 2014). The empirical novelty of these mechanisms offers a unique opportunity for understanding how a variety of actors try to create financial tools that can anticipate how ecosystems' rents are locally undermined by capitalism's second contradiction (O'Connor, 1988).

In order to integrate perspectives from rent theory and biopolitics, I show that insurance can insert risk imaginaries into ecosystems' rents in two ways: firstly, insurance relies on economistic valuations that render rents legible, thus symbolically changing the meaning of an ecosystem in order to determine which natures are worth saving (Dempsey, 2016). As a means of explicating nature's worth, I suggest that reading natural infrastructures through an insurance lens creates a temporal horizon for the rents that an ecosystem previously provided exogenously (that is, as a free gift of nature), but for which capital (and the state) seeks to compensate as the ecosystem deteriorates. In the case of a coral reef as infrastructure, it is the reef's protective capacities that offer rents relative to sites without a reef. Secondly, the premise of existing frameworks for insuring nature assumes that capital is able to restore nature to some extent. Thus, insurance becomes the means of mobilizing capital for mitigating anthropogenic climate change by intervening in the reef. My analysis shows that the benefits from an insured ecosystem can best be conceptualized as a rent and that insurance becomes a means of governing these rents biopolitically, but insurance has its limits when it comes to making nature live.

This paper proceeds as follows: I outline my methodology in the first section. Secondly, I introduce my conceptual framework by elaborating on recent developments in political ecological literature on rent and biopolitics. Third, I review recent debates on the material risks of biodiversity loss and climate change. The following two sections synthesize empirical material with the concept of rent, and analyze the difficulties with subjecting reefs as infrastructure to biopolitical calculation. Finally, I speculate on what kind of Anthropocene we might be heading towards as ecosystems become conceptualized as rent-bearing assets that can be governed biopolitically through insurance.

\section{Methodology}

Empirically, my argument builds on document analysis of official reports, media sources and webinars, attending two conferences where these mechanisms were discussed, and interviews with eleven experts involved with promoting the integration of ecosystem-based adaptation and insurance. Media sources have been used to get a sense of how these new mechanisms are presented publicly and to illustrate the excitement that is created around them. Meanwhile, official reports that thoroughly describe insurance design and expert interviews have allowed me to get a nuanced perspective of the complexities involved with designing these insurance products. Interviews were conducted between January and November 2020. Interviewing experts raises questions about who the expert is, and the nature of the information the expert provides (Bogner et al., 2009). For the purpose of this article, the interviewees have provided information that is part of the re- 
interpretations presented here. Whereas several of the interviewees had been involved in designing projects that integrate parametric insurance and ecosystem-based adaptation, not all interviewees have been engaged with coral reef insurance in Quintana Roo. I have tried to recruit key informants across different projects. Although insurance designs vary, I build on quotes from different interviewees insofar as their views represent general principles behind ecosystem-based insurance products, and I only use information on a specific project when I know the interviewee has an in-depth understanding of the project.

Reckoning analytically with new experimental insurance products will necessarily rely on known experiences in order to speculate about a future that is fraught with uncertainties (Erikson, 2019). Furthermore, the sheer newness of ecosystem-based insurance approaches means that there are limited opportunities for data collection on these emerging approaches. It is likely that more ethnographic studies will be needed in the future. The implication is that this article will build on existing work on parametric insurance by political ecologists (e.g. Johnson, 2013b; 2015; Taylor, 2020) in order to provide a largely conceptual, but nonetheless empirically informed, account. Consequently, I am mainly able to present a re-interpretation of how these projects work in principle.

\section{Governing rents biopolitically}

Scholars working on parametric insurance have conceptualized these mechanisms as biopolitical governance (e.g. Grove, 2010; Johnson, 2013a) and a way for insurance to capture a rent (Johnson, 2015). Whilst Leigh Johnson (2015) does comment on insurance as rent and biopolitics, the two remain largely unconnected in her analysis. By combining perspectives on rent and biopolitics, I advance and nuance scholarship on the transformation of nature into capital (Dempsey, 2016; Fletcher et al., 2019). ${ }^{2}$ Using concepts from urban geography, the integration of insurance and ecosystem-based adaptation can similarly be seen as a way of mitigating climate change, which expresses "rent at risk" while enabling the insurance industry to capture "risk rents" (Taylor and Aalbers, in review). Whereas the concept of rent can be easily outlined as a narrow analytical concept, defining biopolitics simultaneously refers to an analytical concept and historically specific ways of subjecting human and non-human natures to calculative practices.

\section{What is a rent?}

"Rent," as Brett Christophers (2019b, pp. 308-309) writes, "can be defined as income derived from the ownership, possession, or control of scarce assets and under conditions of limited or no competition." Thus, not all of nature's free gifts provide rents: oxygen may be an essential free gift of nature, which conditions human existence as such, but since oxygen is not scarce, it has so far not been possible to cash supernormal profits from accessing it. Instead, Marx's classical example is that of the waterfall, which, given the right historical and social circumstances, the capitalist can use as a cheap energy source and thus use to score a higher profit than those that do not have access to it. Whether a monetary transaction is established around the waterfall is, however, not a necessary condition for its rent-generating capacities (Marx, 1991, p. 784; see also Høst, 2015, pp. 81-108). In the case of the waterfall, it indirectly becomes part of the valorization process as the absence of costs that the capitalist would otherwise have incurred.

Financial capital is increasingly reconfiguring nature in order to capture rents through insurance products, carbon and biodiversity offsets, derivatives and commodity index funds (Ouma et al., 2018, p. 501; Purcell et al., 2020). Deviating from a Ricardian notion of rents as "the original and indestructible powers of the soil" (Ricardo in Kaplinsky, 2005, p. 62; see also Ward and Aalbers, 2016, p. 1762), to take rent "naturally" today implies taking it seriously as an analytical concept that enables us to explain economic phenomena (Birch, 2020, p. 8). Rents cannot be taken for granted as something that nature in itself provides to the economy. Instead, we must "understand economic rents and rent-seeking as a social process and practice rather than a distortion of an idealized and naturalized political-economic process or logic" (Birch, 2020, p. 13).

\footnotetext{
2 The use of individual transferable quotas for fisheries management have similarly both been analyzed as governance of rents through the creation of assets (Høst, 2015) and biopolitics (Bresnihan, 2019).
} 
While we can distinguish between a series of rents, these fundamentally arise from a resource, process or form of knowledge being (made) scarce or able to be monopolized. Even the state can accrue a rent as it serves as the ultimate landlord. Here, it is the interplay between de jure and de facto sovereignty of the state something that is always politically contingent - that allows the state to acquire a rent from the administration of its territory (Emel et al., 2011; Parenti, 2015). What is used in, say, a land rent is "a monopolisable natural force which (...) is available only to those who have at their disposal particular pieces of the earth's surface and their appurtenances" (Marx, 1991, p. 784). Thus, even if a landlord does not have a monopoly on land as such, like a state formally might, the landlord controls a share of a scarce resource. Marx was interested mainly in capitalist property in land - like the classical political economists that he critiqued - which implied "a principle of individuation established through exclusivity of a certain portion of space" (Harvey, 2018, p. 339). However, the concrete ways rents are created and maintained are historically determined and do not always necessitate strict individuation of property relations.

Similar to the "individuation" of commodified nature, which implies "the representational and physical act of separating a specific thing or entity from its supporting context" (Castree, 2003, p. 280), discursive and material techniques can make an entity rent-generating, or merely create a representation that aims to approximate rents. While individuation is a step towards commodifying nature, it is more precise to consider this as pseudo-commodification insofar as the process of making a rent-bearing asset out of nature does not necessarily imply the investment of labor power (Andreucci et al., 2017). When nature is individuated as asset, we could say, using the terminology of Collard and Dempsey (2017, p. 469), that the assetized nature is individuated as either "officially valued" or represented as speculative "reserve army", while the asset may still rely on "the underground" of ecosystem functions that enabled the assetized nature to be seen as valuable. The implications of applying this conceptualization to ecosystems' rents is that whether they become rent-bearing will to some extent depend on how a specific rent-bearing entity becomes symbolically and institutionally individuated from its supporting environment.

\section{What is biopolitics?}

The birth of biopolitics implies a new modality of sovereign power in the $19^{\text {th }}$ century, which is not merely the power "to take life and let life", as Michel Foucault (1978, p. 136) canonically puts it. Instead, Foucault argues, power increasingly "exerts a positive influence on life, that endeavors to administer, optimize, and multiply it, subjecting it to precise controls and comprehensive regulations" (Foucault, 1978, p. 137). However, this liberal modality of power simultaneously puts a limit on sovereign power as its imperative to maintain life cannot be directly controlled by the sovereign, but must be indirectly managed by making the health of the population calculable. In a biopolitical regime, "security mechanisms have to be installed around the random element inherent in a population of living beings so as to optimize a state of life" (Foucault, 2003, p. 246). Thus, Foucault shows that even as the right to take life fades into the background of power, the new apparatus of biopolitical knowledge paradoxically makes power even more pervasive as it creates new avenues for power to intervene in the social body (Foucault, 1978, p. 142).

Since Foucault's analysis, biopolitical apparatuses have expanded to such an extent that "most forms of biological life, some might even say all forms of life, including life itself, have been economized" (Bird and Lynch, 2019, p. 305). Today, various forms of nature are being subjected to biopolitical apparatuses that codetermine what natures live and what natures die, or are at least not worth saving (Margulies, 2019). Even within the literature on conservation biopolitics, scholars have uncovered a multitude of approaches for representing and creating biopolitical principles for the governance of conservation (Biermann and Anderson, 2017). Following Connor Cavanagh's (2018) comprehensive review of biopower in political ecology, biopower over non-human nature, put concisely, is about subjecting nature to explicit calculation to secure power over nature. Similarly, within climate change adaptation literature, Grove argues that biopolitical principles "endeavor to render life amenable to calculated governmental interventions" (2014, p. 199). Since the biopolitical mode of governing non-human life presents itself merely as a technical optimization solution, it tends to depoliticize itself and its implications for how we relate to nature (Biermann and Mansfield, 2014; Dempsey, 2016). 
Biopolitics thereby involves establishing the boundary between the human and the non-human as well as mobilizing techniques for governing both (Lemke, 2015). While there might be several ways of relating to nature within the capitalist mode of production, the mode of production nonetheless fundamentally conditions the relation between humans and non-human nature insofar as the production of nature becomes informed by the social imperative to realize value through market-mediated exchanges in capitalism (Smith, 2008). Building on notions of biopolitics, Stephanie Wakefield (2020) has analyzed the production of nature as infrastructure and how this requires work by humans and oysters alike. The production of oyster reefs as protective infrastructure is biopolitical as it is "a governmental technique to secure existing liberal, capitalist human life" and since it involves "humans trying to make nature appear and live in a particular way - not according to a social norm, but in the way they imagine is natural to oysters" (Wakefield 2020, p. 764).

Although Wakefield (2020) does not see nature-based infrastructure as leading to commodification per se, reading environmental management through a biopolitical lens accentuates the economic logic underpinning protection of nature. As Christine Biermann and Becky Mansfield (2014, p. 260) write, "extending biopower to consider human-nonhuman relations allows us to understand the preservationist and capitalist logics not merely as opposing forces, but as connected through the vast networks in which power circulates." It might be Michael Hardt and Antonio Negri (2009) who have come closest to a notion of biopolitics as not just economic, but as specifically resulting in rents. They conclude that the biopolitical exploitation of the commons - which does not merely include nature, but also immaterial, cultural and affective production of society as such - can most adequately be described as a rent that capital acquires insofar as it "is generally conceived as an external mode of extraction" (Hardt and Negri, 2009, p. 141).

As the following analysis will show, biopolitics of nature is intimately connected to the non-human production of uncertain rents. By designating relevant populations that need vital optimization, biopolitical tools are mobilized for reproducing, potentially individuating, future rents. Rather than securing reproduction of vast ecosystems (Baldwin, 2013), I explore the biopolitical governance of rents that a relatively delimited ecosystem provides to specific actors, the planning of deteriorating rents and strategies to recompense deteriorating rents with capital investments, which involves "enrolling the self-organizing capacities of ecosystems themselves as productive forces" (Nelson, 2015, p. 465).

\section{Environments at/of risk}

To understand the integration of ecosystem-based adaptation and insurance, it is necessary to outline two separate, but related discourses: climate change and biodiversity loss as material, but ultimately, systematic risks. Over the last decade, discourses on climate change and biodiversity loss as material risks have started to circulate in the global policy sphere as witnessed with the persistence of environmental concerns featuring prominently in The World Economic Forum's Global Risks Report (2020). Within the biodiversity sphere, there has been a push toward speaking about biodiversity as good corporate social responsibility and viewing the loss of biological diversity as a financial risk to companies, an underlying indicator that businesses need to take account of. Yet, this discourse remains "sharply disconnected from the present-day priorities and realities of businesspeople and the financial world at large, wherein relatively little concern exists regarding ecosystems and biodiversity" (Dempsey, 2016, p 138). Similarly, the Global Risk Report says "All businesses should account for ecological risks to their operations and reputations, yet few do" (World Economic Forum 2020, p. 48, emphasis added).

Various organizations are similarly reframing climate change as a material risk that any self-interested company or investor must heed to survive economically. Yet, due to factors such as market power, shorttermism and the epistemological problem of climate change representing uncertainty rather than rationally calculable risks, discourses on the materiality of climate risks have had a limited effect on changing investments through disclosure (Christophers, 2017). As Christophers (2019a) concludes, investors keep investing in fossil fuel companies even as they are perfectly aware this is incompatible with climate change targets.

Two recent developments that anticipate future environmental breakdowns are ecosystem-based adaptation (which is also sometimes referred to as a nature-based solution) and parametric insurance products. These developments have emerged as a response to increasing climate risks and aim to make systemic climate and biodiversity risks operational on a local scale. Furthermore, they both respond to insurance discourses 
regarding the "global protection gap" (Taylor, 2020, p. 1135), which claims that people and assets are underinsured (Booth and Kendal, 2020). The ecosystem-based adaptation approach frames ecosystems as infrastructures that provide protective capacities for people and capital (Opperman, 2014; World Bank, 2017), but whilst these protective assets play a critical role as environmental hazards become more significant, protective ecosystems are themselves at risk due to climate change. Recent studies claiming that without mangroves "...39\% more people would be flooded annually, and flood damages would increase by more than 16\% and US \$82 billion annually" (Losada et al., 2018, p. 5) or that "the annual value of flood risk reduction provided by U.S. coral reefs is more than 18,000 lives and \$1.805 billion in 2010 U.S. dollars" (Storlazzi et al., 2019, p. 1) are used to underpin the role of ecosystems as protective infrastructures. Thus, ecosystems are not only resilient systems, but also a condition for capital's resilience (Nelson, 2014).

Meanwhile, new insurance products seek to create adaptation to changing climate conditions, not by supporting protective structures ex ante, but by providing financing ex post through insurance. Examples include the rise of parametric weather insurance and catastrophe bonds, which are not based on actual losses like traditional indemnity insurance is. Rather, insurance payout is contingent on a predefined trigger being met (such as the wind speed of a hurricane). The implication of this design is that some events might lead to damage to an insurance holder's property, but if the conditions for payout are not met (such as a lower intensity weather event), then there is no compensation. Similarly, it is possible to imagine a scenario where the insurance holder's property is not damaged, but the triggering conditions are met. This discrepancy between actual losses and the compensation is known as "basis risk" (for an outline of these approaches, see Johnson, 2011; Scherer, 2020; Knudson, 2018).

Modern parametric insurance and related financial derivatives have gradually made it increasingly possible to bet on weather events. Whereas insurance law typically requires a party to have a legitimate interest in the object being insured, new types of parametric insurance and catastrophe bonds increasingly detach the insured party from the insured asset since these insurance products in principle could function as a mere bet (Knudson, 2018). This has become possible as the division between insurance and finance has gradually broken down and boundaries of insurability have continuously expanded (Johnson, 2011; Scherer, 2020).

These insurance approaches have nonetheless been framed as tools for achieving sustainability, successful adaptation to risks, and even political stability (Christophers et al., 2020; Grove, 2012). While parametric insurance, index-linked securities and catastrophe bonds have a complicated history that is conditioned by weather events, scientific development and the economic challenges of the insurance industry (Johnson, 2011), they rose to further prominence in development policy following the 2007 Bali Action Plan by the United Nations Framework Convention on Climate Change that put adaptation and climate mitigation on an equal footing (Scherer, 2020, p. 2). Since then, new insurance products have become seen as a tool for achieving the sustainable development goals and manage risks prudently, although some researchers argue that these mechanisms are little else than tools for excess profit-making, which are rarely correlated with actual catastrophe events and do little to address actual environmental threats (Etzion et al., 2019; see also Grove, 2021).

\section{Insuring environments at/of risk}

This subsection turns to the integration of ecosystem-based adaptation and insurance and how these fit within the discourses on material risk. In recent years, ecosystem-based adaptation and insurance have made some initial steps in becoming integrated, since ecosystems are framed as "a first line of defence" against worsening weather events (Ferrario et al., 2014). These approaches are brought together by an ensemble of actors trying to make new insurance (Collier et al., 2021; Scherer, 2020) and conservation markets (Christiansen, 2021). Ecosystem-based adaptation and insurance is integrating climate risk and biodiversity loss as material risk since this approach simultaneously highlights the increased risks from climate change and how biological diversity can protect assets against climate change. As the authors of a TNC and UNDP report write (Deutz et al., 2017, p. 6), 
As the insurance, development and conservation sectors move closer together, natural capital has become the new frontier for insurance and development, with insurance products created to protect natural capital.

One of the most prominent examples of this is the coral reef insurance that TNC developed for the Coastal Zone Management Trust in the Mexican state Quintana Roo. While practitioners working on the integration of ecosystem-based adaptation and insurance that I have interviewed argue that insurance designs are context-specific - and thus the Coastal Zone Management Trust model and its coral reef insurance should not be seen as an ideal type for all nature-based insurances - the project has received a lot of publicity. "A portfolio of global reef insurance policies", the insurance news outlet Artemis (2018b) wrote, "combined with investments to finance resilience could become an entirely new and relatively uncorrelated asset class, which could be attractive to existing ILS [insurance-linked securities] investors as well" (see also Evans, 2019b). As an interviewee explained, the first year of coverage was funded by TNC and the state government of Quintana Roo and renewed by the state government in 2020. The original proposal was that the municipal governments - rather than the state government - would fund the policy through taxation of coastal property owners, but this has so far proven politically difficult. The policy was triggered for the first time when hurricane Delta hit Quintana Roo in October, 2020.

Rather than the financialization of marine space happening through enclosures (Barbesgaard, 2018), the parametric insurance dissociates the insurance product and the underlying coral reef. As Kousky and Light (2019, p. 373) write,

If, for example, a coral reef straddled a geographic or national boundary, an insurance policy could be developed on a global or multinational scale to include private parties and government actors on both sides of the boundary. There is no clear geographic limit to who can participate in the creation of a multiparty trust fund to purchase insurance, or who could be insured under a single parametric policy. This is a significant advantage over certain other forms of ecosystem governance.

As the senior vice president of global partnerships at Swiss Re explained publicly: "The innovation here is not the insurance policy itself, that is, it's not the mechanism by which we calculate the insurance premiums and proceeds. The innovation here is that we're insuring something that no one owns" (quoted in Carr, 2018). We could say that this ability to insure something that no one owns is in the very DNA of parametric insurance since "catastrophe models turn an illiquid asset (...) into a liquid commodity" (Grove, 2012 p. 147), which in turn "allows financial companies to sell insurance contracts on nothing but the risk of a hurricane turning up" (Knudson, 2018, p. 85). Paraphrasing Horkheimer and Adorno (2002, p. 3), we might consequently say that on their way toward modern insurance for ecosystems "human beings have discarded meaning. The concept is replaced by the formula, the cause by rules and probability." Despite advocates of insurance for ecosystems trying to account for the monetary value of ecosystem services, the construction of parametric insurance for an ecosystem could therefore in principle be completely disconnected from such valuations. ${ }^{3}$ Compensation is thus based on a buyer and a seller's agreement regarding the likelihood of an extreme weather event and the necessary premium.

Since TNC made their deal public, a number of partnerships to promote this approach have been announced. TNC has received support from Bank of America to replicate the concept for Florida and Hawaii (Berg et al., 2020). TNC is similarly working with UNDP to potentially promote the concept to "Indonesia, Philippines, Malaysia, the United States (Hawaii and Puerto Rico), The Bahamas, Mauritius, Taiwan, Vietnam, Saudi Arabia, Dominican Republic, Puerto Rico, UAE, Fiji, Belize, Myanmar, Thailand, Vanuatu, Trinidad \&

\footnotetext{
${ }^{3}$ An interviewee from the insurance industry furthermore explained how they were thinking about designing an insurance that was not linked to any asset, but instead was linked to flows. This could for example be used to insure an MPA manager against declining tourist numbers as the number of tourists could then function as trigger.
} 
Tobago, Guatemala and Costa Rica" as well as "actively examining the potential for other natural capital assets that can be insured, such as coastal marshes and mangroves" (Deutz et al., 2017, p. 8). ${ }^{4}$

Besides the Coastal Zone Management Trust in Quintana Roo, the deal that is potentially furthest ahead is the parametric insurance for the Mesoamerican reef. This concept was conceived in 2010 when the Mesoamerican Reef Fund (MAR Fund), established for marine ecosystems conservation in Belize, Guatemala, Honduras and Mexico, collaborated with a consultant who had developed parametric insurance for agricultural production on the African continent. However, it was not until 2017 that the work to materialize the idea started. Rather than covering a single coral reef in a nationally defined space, the parametric insurance for this product is planned to cover reefs in the four member countries (Artemis, 2018a). ${ }^{5}$ As of March 2020, the plan was for MAR Fund to secure funding to buy the insurance to prove its worth to the national governments that would then have to buy future insurance policies.

Conservation International (CI) is likewise developing a project that will integrate ecosystem-based adaptation and insurance, which is named the Restoration Insurance Service Company (RISCO). RISCO aims to invest in mangroves to decrease insurance costs. However, the prime objective of RISCO is not a parametric insurance policy (although the developers are considering placing a parametric insurance on the mangroves in order to reduce project risks). Instead, RISCO aims to restore mangrove forests and write contracts with local Philippine (Pinoy) insurance companies that can reduce the costs of future indemnity claims as the mangroves would protect insurance holders from damaging events (Conway and Mazza, 2019). While RISCO thus try to use ecosystem-based adaptation as a protective tool like the Coastal Zone Management Trust coral reef insurance, it is structured differently; it seeks to make investments into ecosystem-based adaptation before a catastrophic event. Thus, rather than insuring nature, these projects are about using nature as insurance. In other words, the Coastal Zone Management Trust coral reef insurance is primarily about insuring an ecosystem that indirectly creates benefits for the adjacent hotel industry whereas RISCO is about establishing a transaction around the production of an ecosystem whose primary function to function as a protective infrastructure.

Whilst there are differences between these projects, what they have in common is that they mobilize insurance and risk perceptions in order to reinterpret and potentially change coastal areas. "If we are to take the association between climate adaptation and insurance seriously, we also need to see how changes in the natural and built environment will reduce exposure to risk" as insurance designers note (Jarzabkowski et al., 2019, p. 28). This sentiment is being realized in the development of an Ocean Risk Index that aims to represent insurance risks with and without existing ecosystems (Evans, 2019a). ${ }^{6}$ Given the variety of approaches taken, it is not surprising that the actors engaged with this overall framework of integrating insurance and ecosystem-based adaptation self-consciously articulate it as an experimental approach that will be context-dependent,

This is still so new and in process that it's hard to say how wide-reaching this could be. It could end up being a very narrow scope of application, I mean, just seeing how we've been struggling to find an end-client where there's all the right suitable enabling factors. (...) I mean the interesting thing and what's really exciting is that you are tapping into this new, potentially very scalable source of financing to restore your coral reefs around the world. The big problem is, where is this actually applicable? And maybe the scope is too narrow. I'm not sure yet. Maybe there's better investment of time and energy. I'm not sure (...) There's a lot of experimentation.

\footnotetext{
${ }^{4}$ More recently, the United Nations Environment Programme and WWF (2019, p. 30) drew inspiration from TNC's project in Quintana Roo and suggested that world heritage sites could be parametrically insured.

${ }^{5}$ This project is supported by a variety of actors, such as the insurance company Willis Towers Watson, TNC, the German development bank KfW and InsuResilience (Artemis, 2018a). InsuResilience was initiated as a G7 partnership in 2015 and became expanded to a G20 partnership in 2017 (Knudson, 2018, p. 78; Scherer, 2020, pp. 2-3). As InsuResilience (2019, p. 45) writes in its annual report, a "priority for 2020 is to facilitate follow-up work relating to these activities, for example developing an action plan for the Partnership to promote nature-based solutions."

${ }^{6}$ This is only one of several approaches (World Bank, 2016), which also includes the Natural Capital Project's InVEST tool (Dempsey 2016, p. 105ff.)
} 
Such experiments in making nature into protective infrastructures require two things: linking the economic benefits of an ecosystem - something we can best describe as rents - to specific economic actors and secondly, being able to draw ecosystems into modes of calculation that can anticipate the contingent threats.

\section{Infrastructuring coastal ecosystems}

The coral reef insurance represents yet another way in which The Nature Conservancy pursues conservation through exchange values as a political strategy (Dempsey, 2016). While the economic imperative for ecosystem-based insurance is not the only one, it is certainly a central one. ${ }^{7}$ As one interviewee explained, coral reef insurance "has focused the resort developers and managers on the reef, the function of the reef and how valuable it is in terms of their business" (see also Einhorn and Flavelle, 2020). More specifically, TNC hopes that "the severity of the damage caused by hurricanes to coral reefs and the negative impact on the ecosystem services they provide" will imply that "beneficiaries and entities responsible for the reefs have high stakes in repairing the damages" (Secaira Fajardo et al., 2019, p. 4). This is in terms of securing coastal assets from flooding, preventing coastal erosion and maintaining the corals as a tourist attraction (Secaira, 2017). As the Governor of the State of Quintana Roo said (in Artemis, 2018b), "The Coastal Zone Management Trust and insurance for beaches and reefs are key elements for the protection of the coastal infrastructure, economy and jobs of the most important tourist destination in Mexico". This is not least, as he is furthermore quoted, because

The Mexican Caribbean is visited by nearly 12 million tourists every year, which generate around 9 billion USD to the country, but these benefits are threatened by the possible presence of natural disasters such as hurricanes and storms that cyclically put us in risk. We have the advantage of being protected by the Mesoamerican Reef and that is why we are committed to the recovery and protection of our beaches and reefs.

Indicating the role of insurance as a tool for public agencies (Collier and Cox, 2021), Willis Towers Watson and the MAR Fund (2019b, p. 5) similarly appeal to the economic value of coral reefs as natural infrastructure that requires maintenance, mapping of beneficiaries and investment in their proposal for coral reef insurance:

Like roads and bridges, natural assets can be thought of as public infrastructure, and even though they do not often feature explicitly on government asset lists or balance sheets, revenue streams depend on their presence and continued health. Therefore, like grey infrastructure, communities must establish financial responsibility for the care and upkeep of natural assets, otherwise risking significant stress to the industries and financial flows that depend on their functioning.

"Blue infrastructure finance", which is a term that has recently evolved amongst some actors in development, epitomizes this idea by promoting the notion that natural ecosystems are more cost-effective than conventional infrastructure projects (Thiele et al., 2020). Furthermore, framing nature as infrastructure is a way of tapping into public infrastructure funds that typically do not support ecosystems (Towers Willis Watson and MAR Fund, 2019a, p. 7; Colgan et al., 2017). Thus, like catastrophe insurance in general (Grove, 2010, p. 554), insuring natural infrastructures aims to make new funding streams possible, but when the insured asset is an ecosystem, the possibility of raising new sources of financing is contingent on modelers' ability to represent the economic benefits of the ecosystem. Besides insurance being able to capture value because of the insurance-

\footnotetext{
${ }^{7}$ Moral imperatives of protecting people cannot be separated from this approach either. Similar to other financial solutions in the "Blue Economy" (Barbesgaard, 2018), the introduction of insurance for coral reefs has been presented as a win-winwin solution and a way to bring private capital to conservation. Insurance have been introduced as a way to create natural capital values for reefs and find ways to make reefs more resilient by speeding up recovery and help local communities (Artemis, 2018a; 2018b). Thus, insurance for biodiversity continues the process of expanding insurance markets whilst insurers can present their work as philanthropic (Peterson, 2012, p. 577).
} 
holder's fear of future catastrophes (Johnson, 2011), modelers aiming to create insurance products must show that when the ecosystem becomes conceptualized as infrastructure, it can provide services that are worth insuring.

Thus, a key component, if these models are to become a viable financial product for conservation, is that their economic rhetoric is persuasive (Mccloskey, 1983). Expanding parametric insurance to new markets can be difficult since, as Leigh Johnson (2013b, p. 2674) writes, "insurance is not a tangible product or service rendered at the time of payment, but rather an intangible promise of future financial exchange contingent upon the occurrence of an undesirable event." As a financial consultant explained in an interview, when constructing an insurance policy for a coral reef, "the biggest issue is on demand sophistication", which involves "making sure that the local community and government know to ask for insurance, know how to sell insurance, know how to apply it and implement it." When it is a coral reef that is insured, the people demanding insurance furthermore need to acknowledge the relatively intangible benefits of the reef. A report from the MAR Fund explains that the fact that it is only a single party being compensated in order to carry out restoration work rather than a series of individuals being compensated for lost commodities - it will be easier to sell the policy (Wagner et al., 2019, pp. 12-13).

The implication of this is that risk modelling needs to be operationalized on the appropriate, local scale (Soto-Montes-de-Oca et al., 2020). One interviewee contrasted the protective role of natural infrastructure with "esoteric" carbon markets since the former "actually provides real local benefits", which implies that "you can actually model pretty well the economic value that it's providing to local assets":

The way that I see it from a green infrastructure perspective is, you know, nature being a bit like a machine, or maybe it's machines being like nature. Nature produces things, produces goods and services. So in the same way you invest in either building infrastructure or upgrading infrastructure, knowing that you are going to have a return on investment because the goods and services that are produced from your investments, the revenues from that, you know, the net present value exceed the cost of investment you have (...) You can do that for traditional infrastructure, you can do that for green infrastructure, right. And so, the thinking is to say, well, what are the goods and services that nature produces that an investment could actually enhance the production of those goods and services.

As Sara Nelson and Patrick Bigger (2021) highlight, such practices and discourses regarding what they critically term "infrastructural natures" are not just about reframing nature, but an attempt to reconfigure nature as infrastructure. In the case of TNC's insurance in Quintana Roo and the MAR Fund's attempt to build an insurance for the Mesoamerican reef region, these are conditioned on the state as ultimate landlord that benefits from sovereign control over its territory and for whom there is an imperative to supply sectors of the economy with use values (Emel et al., 2011; Parenti, 2015).

To understand the services that these infrastructures provide in political economy terms, it is useful to return to Marx's reflections on land rent. Recalling Marx's (1991) discussion of the capitalist's use of the waterfall, if two landowners are equally exposed to hurricanes, a landowner whose land is adjacent to a wellfunctioning reef is securing a rent vis-à-vis a landowner whose land is not. However, this logic is naturally based on all things being equal, which is hard to find in actual empirical examples; in reality, non-enclosed rents can present themselves as the total sum of free gifts of nature.

As hurricanes grow stronger and more frequent or ecosystems that protect built assets deteriorate, rents similarly deteriorate. Thus, Zac Taylor (2020) is right to assert that novel forms of index-linked securities in the insurance industry are just as much about a crisis of the built environment as it is a crisis for the insurance industry (which it can of course profit from). Insofar as worsening weather conditions require increased capital to compensate for climate risks (Elliott, 2019), an ecosystem that alternatively protects land and property can be understood as providing a free rent. An ecosystem not only generates a rent in relation to the capital it is protecting, but it furthermore depends on its ability to mitigate the economic effects of an uncertain catastrophe. As a way of planning for resilience (Wakefield, 2018 p. 5), the ecosystem provides a rent insofar as it mitigates 
the catastrophe as a deterioration of land rent (see also Taylor \& Aalbers, in review). However, whereas Marx (1991, p. 784) claimed that the conditions of a rent "is to be found in nature only at certain places, and where it is not found, it cannot be produced by a particular capital outlay", the attempt to insure ecosystems themselves or create natural infrastructure as part of an insurance product is exactly an attempt to substitute natural conditions for a capital outlay. ${ }^{8}$ Representing ecosystems as protective infrastructure that can be insured, or can be part of insurance, not only pushes the limits for what is insurable; it furthermore aims to push the limits of the production of nature (Miller and Mitchell, 2017; Smith, 2008).

Insuring a coral reef essentially needs to operate as if monetary values and rents are given (Beckert, 2016). In other words, the valuation of the coral reefs is based on the belief that the present monetary value of tourism can be projected into the future. Thus, catastrophe insurance does not merely rely on making an uncertain future calculable (Bougen, 2003; Johnson, 2013a), but the insurance holder similar needs to have faith in the future of their assets. Similar to other parametric insurance products, "mitigation and asset protection at the individual and community levels will neglect non-local sources of vulnerability" (Peterson, 2012, p. 569). A likely external source of vulnerability that remains unarticulated in this framework would be a decline in tourism, which would potentially lead to a decline in economic activity and the monetary value of built assets in the region.

\section{Insuring nature, governing uncertainty}

In this section, I outline some of the techniques and epistemologies that are being mobilized to insure reefs as infrastructure. Insurance techniques can be seen as serving biopolitical aims in several ways. Not only is insurance for nature biopolitical insofar as it tries to secure economic relations with ecosystems (Biermann and Anderson, 2017; Foucault 1978, pp. 140-141; Dempsey, 2016) as the previous section showed; the protection of economized ecosystems is also biopolitical as it involves anticipating an uncertain future through calculative practices that can make nature live (Baldwin, 2013; Cavanagh, 2018). Paraphrasing Foucault (1978, p. 142), ecosystem damage is not "an inaccessible substrate that only [emerges] from time to time, amid the randomness of death and its fatality; part of it [passes] into knowledge's field of control and power's sphere of intervention." The contingent pathways that have led to the construction of usable data and the institutional requirements of the insurance industry set limits for the biopolitical governance of nature through insurance. In other word, biopolitics has its own limits on governing contingent life (Nelson, 2014; Wakefield, 2020). Building coral reef insurance takes continuous refinement by foresighted planners, and while future products may be based on indemnity insurance models, the parametric coral reef insurance nonetheless demonstrates how designers need to navigate the boundary between risk and uncertainty.

In order to construct a parametric insurance, you need to make "a cat in a box" as some interviewees called it. In other words, it needs to be defined what characterizes a catastrophe within a given geography (or polygon). For the Mexican reef insurance, TNC and Swiss Re used a previous study of the damages caused by hurricanes on reefs. They therefore designed four scenarios: one that did not need insurance and three that led to varying payouts depending on the severity of the hurricane (Secaira Fajardo et al., 2019, p. 17). Specifying the exact dimensions of the polygon was important for the first trigger of the insurance, as the insurance was triggered at the outer limits of the polygon by hurricane Delta. If the polygon had been smaller, the insurance might not have been triggered since the hurricane would not have been strong enough to trigger the insurance near the coast. ${ }^{9}$

\footnotetext{
${ }^{8}$ Marx likewise claims that labor invested in land transforms it into "Earth-capital", but when the landlord sells the land with improvement, the land as a whole appears as rent-bearing for the new buyer (Marx, 1991, p. 757). This would highlight the metabolic and historical nature of labor invested into land (Marx, 1990, p 198), and that rent from land is not categorically (or ontologically) external from land investments, but rather appears external and as a given for capital at a particular moment in time.

${ }^{9}$ At the time the interview was conducted, the interviewee explained that they did not have access to all the data points, which the insurance company had. Therefore, it was not possible to conclusively say whether the insurance would have triggered in the counterfactual scenario that polygon had been smaller.
} 
Building on the experiences from the parametric insurance for reefs in Cancún, a study for the MAR Fund concludes that wind speed at impact, maximum sustained wind speed, percentage of live coral cover and whether the corals face leeward or windward are relevant to take into account when designing the insurance. Based on these parameters, the MAR Fund's consultants considered different polygons and payout scenarios that differed in their granularity. For example, one scenario constructs several polygons for different sites and uses wind speed at impact as the trigger. This allows the policy to have a lower trigger value for sites with a high percentage of coral cover that are more severely impacted by hurricanes. Another scenario offers one trigger for the Mesoamerican region, using maximum wind speed as the parameter, which the authors considered poorly correlated with coral damage but is widely used for parametric insurance. Yet another scenario demarcates polygons according to national boundaries (Secaira et al., 2019). Building insurance consequently requires a very particular form of "nature that capital can see" (Robertson, 2006) that is primarily about making cost-effective models for calculating the risk of a hurricane with an acceptable level of accuracy, not necessarily ascribing value to the reef as such.

As parametric insurance designers acknowledge, "because these products rely on models rather than actual loss, there will always be incomplete information, unknown unknowns, and no model can ever eliminate all error" (Jarzabkowski et al., 2019, p. 12). The basis risk implied in incomplete modelling was experienced in Quintana Roo when the hurricane Zeta hit. As a central architect behind the reef insurance explained in an interview, while hurricane Zeta did not trigger the insurance and the preceding hurricane Delta did, Zeta caused more damage to the reef - perhaps because hurricane Delta had made some of the corals more fragile (see also Einhorn and Flavelle, 2020).

Like other forms of planning for natural infrastructure (Nost, 2020), insuring ecosystems as infrastructure relies on savvy planners that know how to assemble existing data and construct new data within their existing economic and political context. Such data realism, however, can put limits on what is insurable. "The tourism industry of Quintana Roo was primarily interested in insurance to recover from the impacts of Sargasso," as a report by TNC writes, "but such events are new and there are not enough statistics to predict the probability of the event, therefore making it not viable insurance in this pilot" (Secaira Fajardo et al., 2019, p. 4). Thus, historically contingent data collection processes co-determine the viability of insurance and what kinds of insurance can be constructed, which conditions insurance as biopolitics. However, other stressors could be more significant for ecosystem protection (Einhorn and Flavelle, 2020). As an interviewee closely involved with the insurance and trust design in Mexico explained, they would still need to combat overfishing, water pollution and even try to test remedies for diseases that they did not always know how to efficiently address. Some threats may be commonly acknowledged as risks rather than pure uncertainty even if these risks are not subject to entirely formalized calculation (Boholm, 2003). Insuring the coral reef is thus about insuring against an event that is considered calculable relative to other threats that may be acknowledged as risks, but which are not subjected to formal insurance transactions.

Meanwhile, threats that are perceived as certain are unlikely to be insured (Berg et al., 2020, p. 14). We therefore need to add that when the catastrophe is slow and certain, it is difficult to insure against the "event" (Christophers et al., 2020, p. 101). In other words, if parametric insurance becomes a widespread tool for insuring ecosystems, then those events that will certainly destroy ecosystems, such as coral bleaching, are unlikely be insured. However, in principle, this would not make the ecosystem uninsurable as such: if we are certain that ocean acidification and warming seawater will destroy a coral reef, those events might not be insurable, but since parametric insurance is fundamentally only based on a statistical event (Knudson, 2018, p. 85), it would theoretically still be possible to insure the reef against hurricanes that were historically likely to damage the reef. ${ }^{10}$

Finally, the very structuring practices that the insurance industry uses to build models could furthermore become a problem for climate adaptation. Whilst insurers constantly need to expand what they consider insurable risks as part of their competition with other insurers, contracts typically do not extend beyond two

${ }^{10}$ As a representative from the insurance industry explained, even events that will certainly happen can be insured through a life insurance model, which is about when the event will happen. Berg et al. (2020) also consider insuring ecosystems beyond parametric hurricane insurance. 
years, which allows them to continuously readjust risk assessments and insurance premiums (Johnson, 2011). Whilst catastrophe bonds can have a duration of three or five years, "multi-year contracts of sufficient duration to cover a climate adaptation window, of, say, 10 years, would be challenging to implement under a regulatory framework that also demands solvency from insurers" (Jarzabkowski et al., 2019, p. 28). These authors suggest that even if risks remained stable, which they are unlikely to, increased solvency requirements would lead to further costs and these "capital costs would be passed on in premiums, making the product less affordable to potential policyholders" (Jarzabkowski et al., 2019, p. 28). Even if we assume that investing in resilient infrastructure could theoretically be cost-effective, the relative short-termism of the reinsurance sector as a whole and its portfolio techniques could lead to maladaptation because changing weather events could in the long run make ecosystem insurance unviable for either party (see also Einhorn and Flavelle, 2020). The timescale is thus essential for calculating biopolitical risks that the insurance industry can price.

\section{Nature as a risk-bearing subject in the Anthropocene}

Nature should always be regarded intensely internally variegated - an unparalleled field of difference. (David Harvey 2006, p. 87)

According to TNC, "nature is (...) at risk and can suffer severe damages from hurricanes, fires, droughts, oil spills and other natural and anthropogenic events" (Secaira Fajardo et al., 2019, p. IV). Ecosystem insurance offers a sophisticated version of the "ecological-economic tribunal for (nonhuman) life" (Dempsey, 2016, p. 56) as it does not simply attempt to calculate ecosystems' economic contribution or the risk of future biodiversity loss as a way of planning conservation efforts; rather, a parametric insurance for ecosystems combines the two since the likelihood of further expenses associated with repairing the reef after a destructive hurricane can in theory be discounted from the reef's present value. In valuing the coral reef's protective capacities and the likelihood of a hurricane, the valuation methods used situates the coral reef as capital's "underground" and potential hurricanes as "threats" to capital (Collard and Dempsey, 2017) while hoping that the latter in principle can quantified, calculated and potentially mitigated by capital itself. However, as a coral reef restoration scientist explained, a key part of the insurance deal was to make sure that someone valued the reef, but the insurance in itself might not be enough funding for full recovery (see also Einhorn and Flavelle, 2020):

This is all going to help, you know, in a really material way, but I think in my mind anyway the really important word there is help. It's not the silver bullet. You know, where all these insurance interventions are talking about percentages of reduction in damage, percentages of reductions in costs.

Insofar as the insurance succeeds on its own terms, if only partially, it would be akin to a socio-ecological fix by anticipating increased hurricane risks as a very localized threat to local accumulation processes (Ekers and Prudham, 2015; Taylor, 2020). In that event, insurance is aimed at becoming a way of securing the rents ecosystems provide - or at least slowing the pace at which the ecosystem and rents deteriorate. As a way of making uncertain life adapt to climate change (Grove, 2014), insurance for ecosystems can be seen as a biopolitical conservation "technology which aims to establish a sort of homeostasis, not by training individuals, but by achieving an overall equilibrium that protects the security of the whole from internal dangers" (Foucault, 2003, p. 249). This fix specifically mobilizes biopolitical measures to secure uncertain future rents or compensate for the loss of nature's rents. In the case of the TNC deal in Quintana Roo, these are the rents the tourist industry - and indirectly, the state - benefits from.

There are, however, a series of requirements that need to be in place for a coral reef insurance policy to be financially and ecologically successful. Insurance for ecosystems presents different potential Anthropocenes depending on whether these requirements are fulfilled. One scenario is based on the techno-optimism of the ecomodernist. As Anne Fremaux (2017) has argued, the ecomodernist today approaches the breakdown of the 
binary between human society and non-human nature as a justification for further, and more explicit, human intervention in nature (see also Cantor and Knuth, 2019). According to the MAR Fund (2019b, p. 5), "the science of reef repair and recovery, and locking in reef resilience through active intervention (through, for example, planting coral species resilient to rising ocean temperatures and acidity), has developed rapidly, and provides an opportunity to actively reduce, dramatically, the negative impacts of hurricanes on coral reefs." Similarly, the TNC protocol for restoring coral reefs not only involves removing debris immediately after a hurricane, but it also involves growing corals in nurseries for later planting in the reef (Zepeda-Centeno et al., 2019), which is what the payout from Delta would be used for according to an interviewee. The extent to which these kinds of interventions will take place will not only depend on the resources for restoring the reef that become available after the insurance payout is triggered, but it will also depend on the advances by restoration science. Coral reef restoration is conceptually contested (Tickell et al., 2019), and coral restoration science has historically been scattered, with much experimentation being done by NGOs or local entrepreneurs with limited scientific formalization, but this might be changing as more funding is aimed at restoration (science) in the future (Boström-Einarsson et al., 2020). As a coral restoration scientist at TNC explained in an interview,

There is a tension in all of this that we are developing the how to manual for reef restoration at the same time that the insurance products are being developed to fund that reef restoration so there is actually a bit of a race on to try and make sure that we can restore these reefs and use that money to the end that is insured at the same time as figuring out what an insurance product looks like.

What the quote by this restoration scientist should make abundantly clear is that the biopolitics of making the coral reef live through actuarial calculations may face technical limitations after a potential insurance payout since the science of restoring a coral reef is itself developing.

There is no guarantee that the many necessary requirements for insurance as biopolitical protection of the reefs are fulfilled. As with all parametric insurance, insuring nature involves basis risk. Insuring reefs involves a novel form of basis risk because monetary compensation ultimately needs to result in ecological restoration. Whilst the basis risk of conventional parametric insurance can usually be expressed as a quantity of money - the universal equivalent par excellence - this is not the case with insurance for an ecosystem. A farmer that produces a commodity for sale can be compensated with a pot of money if there is a drought, but the compensation of a coral reef in case of a hurricane will rely on using that pot of money for restoration and the compensation for the reef is no better than the labor invested in restoration. As a presenter at a webinar on insurance for coral reefs explained, there is no guarantee that the reefs will recover since the insurance company merely pays out the agreed amount to the holder of the insurance policy. However, after this, it is up to the holder of the insurance to invest in a restructuring of the coral (OpenChannels, 2018).

The reef (or any insured ecosystem for that matter) thus faces a second layer of basis risk as it is compensated. "Nature," as Anne Fremaux (2017, p. 128) writes building on Adorno's concept of nature as nonidentity, "is not only natura naturata (passive matter) but also natura naturans, a self-causing and selfproductive reality, an active process power that ceaselessly and inventively generates new forms of existence." The reef as non-identity opens up the possibility of the reef as non-capital (Nelson, 2014). This involves an agency that "includes refusing to work or be enrolled in governance" (Wakefield 2020, p. 778). It creates a novel basis risk for nature itself as well as the capital whose protection it is part of since monetary compensation of a purely quantitative nature must be successfully transformed into a qualitatively unique nature, which has the potential to escape our control.

\section{Conclusion}

This article has explored how the services of "infrastructural nature" (Nelson and Bigger, 2021) become legible, and possibly even reproduced, through the concepts of rent and biopolitics. Although the coral reefs in Quintana Roo have not been formally commodified, the risk that hurricanes pose to them has enabled the production of insurance rents in the process of securing the reefs biopolitically. This implies demarcating a line 
between risk and uncertainty with varying degrees of calculability. A critical step towards the reefs getting their own insurance was that their economic benefits, which are ultimately a form of rent to regional hotel owners and the state, were legible. While the catastrophe is certainly a risk to capital that can be seen as the deterioration of rents, the effort to reproduce ecosystems as infrastructure by reinvesting insurance payout is a means of maintaining rents for as long as possible. Finding the right economic actors at the right scale as well as producing credible insurance models will determine how much the integration of insurance and ecosystembased adaption will spread. By presenting this argument, I have aimed to advance scholarship on market-based environmental governance by highlighting how biopolitical tools are mobilized to reproduce and redistribute ecosystems' rents.

If the phenomenon of insurance for ecosystems spreads, it will lead to further, maybe more intentional, human intervention in ecosystems. Yet, insurance practices have their own limits in terms of financing ecosystem biopolitics. Furthermore, ecosystem service deals can falter as external conditions change (Bresnihan, 2017, p. 36), and it is an understatement to say that the tourist industry - as well as the ecosystem service deals that rely on it - is currently facing uncertainty in the face of the global COVID-19 pandemic. Besides the technical complications highlighted earlier in this article, a final complication to ecosystem-based adaptation and insurance is that it will ultimately be available for those able to pay (Kousky and Light, 2019). "Higher-income communities", as a report funded by Lloyd's and co-organized by TNC writes, "have more resources to contribute to funding risk reduction and are also more likely to have the capacity to manage the process of investing to reduce risks" (Colgan et al., 2017, p. 23). It is therefore possible that these approaches will be most feasible in high-income regions and places like Florida, where there is already a substantial ILS market (Taylor, 2020) and where TNC have also conducted feasibility studies (Berg et al., 2020). It is complications like these for governing ecosystems through economic instruments that make it necessary to consider an affirmative biopolitics (Grove, 2014) for governing uncertain nature beyond economism, since the people and ecosystems in most need of protection may simply not be able to pay for insurance, or cannot prove their contributions to national GDP.

\section{References}

Artemis (2017). Nature Conservancy pilots insurance fund for coastal resilience. Artemis. Retrieved from https://www.artemis.bm/news/nature-conservancy-pilots-insurance-fund-for-coastal-resilience

Artemis (2018a). New parametric reef insurance \& resilience product to be developed. Artemis. Retrieved from https://www.artemis.bm/news/new-parametric-reef-insurance-resilience-product-to-be-developed/

Artemis (2018b). Swiss Re \& Nature Conservancy partner for parametric coral reef insurance. Artemis. Retrieved from https://www.artemis.bm/news/swiss-re-nature-conservancy-partner-for-parametriccoral-reef-insurance/

Andreucci, D., García-Lamarca, M., Wedekind, J., \& Swyngedouw E. (2017). "Value Grabbing": A political ecology of rent. Capitalism, Nature, Socialism, 28(3), $28-47$. http://doi.org/10.1080/10455752.2016.1278027

Baldwin, A. (2013). Vital ecosystem security: Emergence, circulation, and the biopolitical environmental citizen. Geoforum, 45, 52-61.

Barbesgaard, M. (2018). Blue growth: savior or ocean grabbing?, The Journal of Peasant Studies. 45(1), 130149. http://doi.org/10.1080/03066150.2017.1377186

Beck, M. W., Quast, O., \& Pliegner, K. (2019). Ecosystem-based adaptation and insurance: Success, challenges and opportunities. InsuResilience Partnership.

Berg, C., Bertolotti, L., Bieri, T., Bowman, J., Braun, R., Cardillo, J., Chaudhury, M., Falinski, K., Geselbracht, L., Hum, K., Lustic, C., Roberts, E., Young, S., \& Way, M. (2020). Insurance for natural infrastructure: Assessing the feasibility of insuring coral reefs in Florida and Hawai'i. The Nature Conservancy.

Beckert, J. (2016). Imagined future: Fictional expectations and capitalist dynamics. Harvard University Press.

Biermann, C., \& Anderson, R. M. (2017). Conservation, biopolitics, and the governance of life and death, Geography Compass, 11(10). http://doi.org/10.1111/gec3.12329 
Biermann, C., \& Mansfield, B. (2014) Biodiversity, purity, and death: Conservation biology as biopolitics, Environment and Planning D: Society and Space, 32(2), 257-273. http://doi.org/10.1068/d13047p

Birch, K. (2020) Technoscience rent: Toward a theory of rentiership for technoscientific capitalism, Science Technology and Human Values, 45(1), 3-33. https://doi.org/10.1177/0162243919829567

Bird, G., \& Lynch, H. (2019). Introduction to the politics of life: A biopolitical mess. European Journal of Social Theory, 22(3), 301-316.

Bogner, A. Littig, B., \& Menz, W. (2009). Introduction: Expert interviews - an introductionisepto a new methodological debate. In A. Bogner, B Littig and W. Menz (eds.). Interviewing experts. Palgrave Macmillan.

Boholm, A. (2003). The cultural nature of risk: Can there be an anthropology of uncertainty? Ethnos, 68(2), 159-178.

Booth, K., \& Kendal, D. (2020). Underinsurance as adaptation: Household agency in places of marketisation and financialisation. Environment and Planning A: Economy and Space. 52(4), 728-746. https://doi.org/10.1177/0308518X19879165

Boström-Einarsson, L., Babcock, R. C., Bayraktarov, E., Ceccarelli, D., Cook, N., Ferse, S. C., Hancock, B., Harrison, P., Hein, M., Shaver, E., Smith, A., Suggett, D., Stewart-Sinclair, P. J., Vardi, T., \& McLeod, I. M. (2020). Coral restoration: A systematic review of current methods, successes, failures and future directions. PloS One, 15(1), e0226631. http://doi.org/10.1371/journal.pone.0226631

Bougen, P. D. (2003). Catastrophe risk. Economy and Society, 32(2), pp. 253-274.

Braun, B. (2009). Nature. In N. Castree, D. Demeritt, D. Liverman and B. Rhoads (eds.). A companion to environmental geography. Wiley.

Bresnihan, P. (2017). Valuing nature - perspectives and issues (National Economic and Social Council No. 11). National Economic and Social Council, Dublin.

Bresnihan, P. (2019). Revisiting neoliberalism in the oceans: Governmentality and the biopolitics of "improvement" in the Irish and European fisheries. Environment and Planning A: Economy and Space, 51(1), 156-177. http://doi.org/10.1177/0308518X18803110

Cantor, A., \& Knuth, S. (2019). Speculations on the postnatural: Restoration, accumulation, and sacrifice at the Salton Sea. Environment and Planning A: Economy and Space, 51(2), 527-544.

Carr, S. (2018). Can we insure our way to healthier oceans and ocean communities?. MEAM, 11(4). https://meam.openchannels.org/news/skimmer-marine-ecosystems-and-management/can-we-insureour-way-healthier-oceans-and-ocean

Castree, N. (2003). Commodifying what nature? Progress in Human Geography, 27(3), 273-297.

Cavanagh, C. J. (2018). Political ecologies of biopower: Diversity, debates, and new frontiers of inquiry. Journal of Political Ecology, 25(1), 402-425. http://doi.org/10.2458/v25i1.23047

Christiansen, J. (2021). Fixing fictions through blended finance: The entrepreneurial ensemble and risk

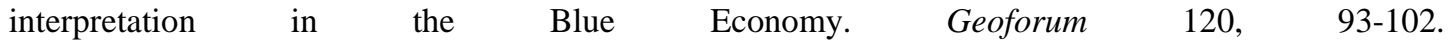
https://doi.org/10.1016/j.geoforum.2021.01.013

Christophers, B. (2017). Climate change and financial instability: Risk disclosure and the problematics of neoliberal governance. Annals of the American Association of Geographers, 107(5), 1108-1127. https://doi.org/10.1080/24694452.2017.1293502

Christophers, B. (2019a). Environmental Beta or how institutional investors think about climate change and fossil fuel risk. Annals of the American Association of Geographers, 109(3), 754-774. http://doi.org/10.1080/24694452.2017.1293502.

Christophers, B. (2019b). The problem of rent. Critical Historical Studies, 6(2), 303-323. http://doi.org/ 10.1080/24694452.2018.1489213.

Christophers, B., Bigger, P., \& Johnson, L. (2020). Stretching scales? Risk and sociality in climate finance. Environment and Planning A: Economy and Space, 51(1), 88-110. http://doi.org/10.1177/0308518X18819004. 
Colgan, C., Beck, M., \& Narayan, S. (2017). Financing natural infrastructure for coastal flood damage reduction. Lloyd's Tercentenary Research Foundation.

Collard, R. C. \& Dempsey, J. (2017). Capitalist natures in five orientations. Capitalism, Nature, Socialism, 28(1), 78-97. http://doi.org/10.1080/10455752.2016.1202294.

Collier, S. J. \& Cox, S. (2021). Governing urban resilience: Insurance and the problematization of climate change. Economy and Society, 50(2), 275-296, http://doi.org/10.1080/03085147.2021.1904621.

Collier, S. J., Elliott, R. and Lehtonen, T.-K. (2021). Climate change and insurance. Economy and Society, 50(2), 158-172. http://doi.org/10.1080/03085147.2021.1903771.

Conway, S. \& Mazza, F. (2019). Restoration Insurance Service Company (RISCO): Lab instrument analysis. The Global Innovation Lab for Climate Finance.

Dempsey, J. (2016). Enterprising nature: economics, markets and finance in global biodiversity politics. WileyBlackwell.

Deutz, A., Kellett, J. \& Zoltani, T. (2017). Innovative finance for resilient coasts and communities. United Nations Development Programme and The Nature Conservancy.

Douglas, M. \& Wildavsky, A. (1983). Risk and culture: An essay on the selection of technological and environmental dangers. University of California Press.

Einhorn, C. \& Flavelle, C. (2020). A race against time to rescue a reef from climate change. New York Times, 5 Dec. Retrieved from https://www.nytimes.com/2020/12/05/climate/Mexico-reef-climate-change.html

Ekers, M. \& Prudham, S. (2015). Towards the socio-ecological fix. Environment and Planning A: Economy and Space, 47(12), 2438-2445. http://doi.org/10.1177\%2F0308518X15617573

Elliott, R. (2019). 'Scarier than another storm': Values at risk in the mapping and insuring of US floodplains. The British Journal of Sociology, 70(3), 1067-1090. http://doi.org/10.1111/1468-4446.12381

Emel, J., Huber, M. T. \& Makene, M. H. (2011). Extracting sovereignty: Capital, territory, and gold mining in Tanzania. Political Geography, 30(2), 70-79. http://doi.org/10.1016/j.polgeo.2010.12.007

Erikson, S. (2019). Global health futures? Reckoning with a pandemic bond. Medical Anthropology Today, 6(3), 77-108. http://doi.org/10.17157/mat.6.3.664

Etzion, D., Kypraios, E. \& Forgues, B. (2019). Employing finance in pursuit of the sustainable development goals: The promise and perils of catastrophe bonds. Academy of Management Discoveries, 5(4), 530554. http://doi.org/10.5465/amd.2018.0137

Evans, S. (2019a). AXA XL wants to create tradable Ocean Risk Index. Artemis. Retrieved from http://artemis.bm/news/axa-xl-wants-to-create-tradable-ocean-risk-index

Evans, S. (2019b). Nature Conservancy targets Florida \& Hawaii for parametric reef insurance. Artemis. Retrieved from https://www.artemis.bm/news/nature-conservancy-targets-florida-hawaii-forparametric-reef-insurance/

Ferrario, F., Beck, M. W., Storlazzi, C. D., Micheli, F., Shepard C. C., \& Airoldi, L. (2014). The effectiveness of coral reefs for coastal hazard risk reduction and adaptation, Nature Communications, 5(1), 1-9. http://doi.org/10.1038/ncomms4794

Fletcher, R., Dressler, W. H., Anderson, Z. R., \& Büscher, B. (2019). Natural capital must be defended: Green growth as neoliberal biopolitics. The Journal of Peasant Studies, 46(5), 1068-1095. http://doi.org/10.1080/03066150.2018.1428953

Foucault, M. (1978[1976]). The history of sexuality, volume 1: an introduction. New York: Pantheon Books.

Foucault, M. (2003[1976]). Society must be defended. Picador.

Fremaux, A. (2017). Towards a critical theory of the Anthropocene and a life-affirming politics: A postanthropocentric, post-growth, post-(neo)liberal Green Republican analysis. Queen's University. http://doi.org/10.13140/RG.2.2.19140.53120.

Grove, K. (2010). Insuring "Our Common Future?" Dangerous climate change and the biopolitics of environmental security. Geopolitics, 15(3), 536-563. http://doi.org/10.1080/14650040903501070.

Grove, K. (2012). Preempting the next disaster: Catastrophe insurance and the financialization of disaster 
management. Security Dialogue, 43(2), pp. 139-155. http://doi.org/10.1177/0967010612438434

Grove, K. (2014). Biopolitics and adaptation: Governing socio-ecological contingency through climate change and disaster studies. Geography Compass, 8(3), 198-210. http://doi.org/0.1111/gec3.12118.

Grove, K. (2021). Insurantialization and the moral economy of ex ante risk management in the Caribbean. Economy and Society, 50(2), 224-247. http:doi.org/10.1080/03085147.2020.1853363

Hardt, M. \& Negri, A. (2009). Commonwealth. Harvard University Press.

Harvey, D. (2006). Spaces of global capitalism: Towards a theory of uneven geographical development. Verso. Harvey, D. (2018[1982]). The limits to capital. Verso.

Horkheimer, M. \& Adorno, T. W. (2002). Dialectic of Enlightenment: Philosophical fragments. Stanford University Press.

Høst, J. (2015). Market-based fisheries management: Private fish and captains of finance. Springer.

InsuResilience (2019). From global ambition to local action: A multi-year vision for enhanced resilience. Bonn: InsuResilience.

Jarzabkowski, P., Chalkias, K., Clarke, D., Lyahen, E., Stadtmueller, D. \& Zwick, A. (2019). Insurance for climate adaptation: Opportunities and limitations. Rotterdam and Washington, D.C.: the Global Commission on Adaptation.

Johnson, L. (2011). Climate change and the risk industry. In R. Peet, P. Robbins, and M. J. Watts (eds.). Global political ecology. Routledge.

Johnson, L. (2013a). Catastrophe bonds and financial risk: Securing capital and rule through contingency. Geoforum, 45, 30-40. http://doi.org/10.1016/j.geoforum.2012.04.003

Johnson, L. (2013b). Index insurance and the articulation of risk-bearing subjects. Environment and Planning A: Economy and Space, 45(1), 2663-2681. http://doi.org/10.1068/a45695

Johnson, L. (2015). Catastrophic fixes: cyclical devaluation and accumulation through climate change impacts. Environment and Planning A: Economy and Space, 47(12), pp. 2503-2521. http://doi.org/10.1177/0308518X15594800

Kaplinsky, R. (2005). Globalization, poverty and inequality: Between a rock and a hard place. Polity Press.

Knudson, C. (2018). One size does not fit all: Universal livelihood insurance in St. Lucia. Geoforum. 95, 7886. http://doi.org/10.1016/j.geoforum.2018.06.023

Kousky, C. \& Light, S. (2019). Insuring nature. Duke Law Journal, 69(323), 323-376.

Lemke, T. (2015). New materialisms: Foucault and the "Government of Things". Theory, Culture and Society, 32(4), 3-25.

Losada, I. J., Menéndez, P., Espejo, A., Torres, S., Díaz-Simal, P., Abad, S., Beck, M. W., Narayan, S., Trespalacios, D., Pfliegner, K., Mucke, P., \& Kirch, L. (2018). The global value of mangroves for risk reduction: Technical Report. The Nature Conservancy.

Margulies, J. (2019). Making the 'man-eater': Tiger conservation as necropolitics. Geoforum, 59, $150-161$. http://doi.org/10.1016/j.polgeo.2018.12.011

Marx, K. (1990[1867]) Capital, Vol. 1. Penguin.

Marx, K. (1991[1894]) Capital, Vol. 3. With F. Engels. Penguin.

Mccloskey, D. N. (1983). The rhetoric of economics. Journal of Economic Literature, 21(2), 481-517.

Miller, S. \& Mitchell, D. (2017). The tight dialectic: The Anthropocene and the capitalist production of nature. Antipode, 49(S1), 75-93. http://doi.org/10.1111/anti.12188

Nelson, S. (2014). Resilience and the neoliberal counter-revolution: From ecologies of control to production of the common. Resilience, 2(1), 1-17. http:doi.org/10.1080/21693293.2014.872456

Nelson, S. (2015). Beyond the limits to growth: Ecology and the neoliberal counterrevolution. Antipode, 47(2), 461-480. http://doi.org/10.1111/anti.12125

Nelson, S. \& Bigger, P. (2021). Infrastructural nature. Progress in Human Geography, 0309132521993916. 
http://doi.org/10.1177/0309132521993916

Nost, E. (2020). Infrastructuring "data-driven" environmental governance in Louisiana's coastal restoration plan. Environment and Planning E: Nature and Space, 2514848620909727. http://doi.org/ $10.1177 / 2514848620909727$

OpenChannels (2018). Insuring nature: An insurance policy for the Mesoamerican Reef. Retrieved from https://vimeo.com/257962407

Ouma, S., Johnson, L. \& Bigger, P. (2018). Rethinking the financialization of 'nature'. Environment and Planning A: Economy and Space 50(3), 500-511. http://doi.org/10.1177/0308518X18755748

Opperman, J. J. (2014). A flood of benefits: Using green infrastructure to reduce flood risks. Arlington: The Nature Conservancy.

Parenti, C. (2015). The 2013 Antipode AAG Lecture. The environment making state: territory, nature, and value. Antipode 47(4), 829-848. http://doi.org/10.1111/anti.12134.

Peterson, N. D. (2012). Developing climate adaptation: The intersection of climate research and development programmes in Index insurance. Development and Change, 43(2), 557-584. http://doi.org/10.1111/j.1467-7660.2012.01767.x.

Purcell, T., Loftus, A. \& March, H. (2020). Value - rent - finance. Progress in Human Geography, 44 (3), 437456. http://doi.org/10.1177/0309132519838064.

Robertson, M. (2006). The nature that capital can see: science, state, and market in the commodification of ecosystem services. Environment and Planning D: Society and Space, 24(3), 367-387. http://doi.org/ $10.1068 / \mathrm{d} 3304$.

Scherer, N. (2020). Insuring against climate change: The emergence of regional catastrophe risk pools. London: Routledge.

Secaira, F., (2017). Building financial resiliency against climate risk in the Mexican Caribbean. The Nature Conservancy.

Secaira, F., Perez, S., Pool, G. T., \& Origel, J. F. T. (2019). Proposal of a parametric insurance in the Mesoamerican Reef. Mesoamerican Reef Fund.

Secaira Fajardo, F., Mcleod, K. B., \& Tassoulas, B. (2019). Guide on how to insure a natural asset. The Nature Conservancy.

Smith, N. (2008) Uneven development: nature, capital, and the production of space ( $3^{\text {rd }}$ ed.). Routledge.

Soto-Montes-de-Oca, G., Bark, R., \& González-Arellano, S. (2020). Incorporating the insurance value of periurban ecosystem services into natural hazard policies and insurance products: Insights from Mexico. Ecological Economics, 169, 106510. http://doi.org/10.1016/j.ecolecon.2019.106510

Storlazzi, C.D., Reguero, B.G., Cole, A.D., Lowe, E., Shope, J.B., Gibbs, A.E., Nickel, B.A., McCall, R.T., van Dongeren, A.R., \& Beck, M.W. (2019) Rigorously valuing the role of U.S. coral reefs in coastal hazard risk reduction.šs: U.S. Geological Survey. http://doi.org/10.3133/ofr20191027

Taylor, Z. J. (2020). The real estate fix: Residential insurance-linked securitization in the Florida metropolis. Environment and Planning A: Economy and Space, 52(6) 1131-1149. http://doi.org/ 10.1177/0308518X19896579

Taylor, Z. J. \& Aalbers, M. B. (in review). Climate gentrification: risk and rent in Miami Dade County.

Thiele, T., Alleng, G., Biermann, A., Corwin, E., Crooks, S., Fieldhouse, P., Herr, D., Matthews, N., Roth, N., Shrivastava, A., von Unger, M., \& Zeitlberger, J. (2020). Blue infrastructure finance: A new approach, integrating Nature-based Solutions for coastal resilience. IUCN.

Tickell, S. C., Sáenz-Arroyo, A., \& Milner-Gulland, E.J. (2019). Sunken worlds: the past and future of humanmade reefs in marine conservation. BioScience, 69(9), 725-735. DOI: 10.1093/biosci/biz079.

United Nations Environment Programme \& WWF. (2019). Protecting our world heritage, insuring a sustainable future: The first guide for the global insurance industry to protect our world's priceless and irreplaceable assets. United Nations Environment Programme and WWF.

Wagner, N., Alderman, H. H., \& Alderman, C. (2019). Concept note for MAR Fund's Reef Rescue Initiative. 
Mesoamerican Reef Fund.

Wakefield, S. (2018). Infrastructures of liberal life: From modernity and progress to resilience and ruins. Geography Compass, 12(7). http://doi.org/10.1111/gec3.12377.

Wakefield, S. (2020). Making nature into infrastructure: The construction of oysters as a risk management solution in New York City. Environment and Planning E: Nature and Space, 3(3) 761-785. http://doi.org10.1177/2514848619887461

Ward, C. \& Aalbers, M. B. (2016). Virtual special issue editorial essay: "The shitty rent business": What's the point of land rent theory?. Urban Studies, 53(9), 1760-1783. http://doi.org/10.1177/0042098016638975.

Willis Towers Watson \& MAR Fund (2019a). Beneficiaries of rapid response reef risk financing in the MAR region. InsuResilience Solutions Fund.

Willis Towers Watson \& MAR Fund (2019b). Sustainability of rapid response reef risk financing in the MAR region. InsuResilience Solutions Fund.

The World Bank (2016). Managing coasts with natural solutions: Guidelines for measuring and valuing the coastal protection services of mangroves and coral reefs. The World Bank.

The World Bank (2017). Implementing nature-based flood protection. The World Bank.

World Economic Forum (2020). The global risks report. World Economic Forum.

Zepeda-Centeno, C., Padilla-Souza, A. C., Huitrón-Baca, J.C., Macías-Constantino, M., Shaver, E., NavaMartínez, G. G., \& García-Salgado, M.A. (2019). Early warning and rapid response protocol: Actions to mitigate the impact of tropical cyclones on coral reefs. The Nature Conservancy. 